\title{
CIVIL LIABILITY FOR INJURIES CAUSED BY DOGS AFTER TRACEY V. SOLESKY: NEW PATH TO THE FUTURE OR BACK TO THE PAST?
}

\section{Alberto Bernabe*}

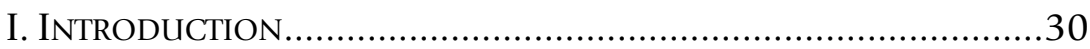

II. The Policy Debate Before TRACEY V. SOLESKY .......................30

III. BASIC PRINCIPLeS RELATED tO CiVIL LIABILITY FOR INJURIES

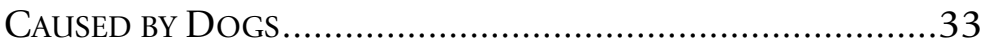

IV. Tracey V. Solesky: A Third Possible Approach to Strict

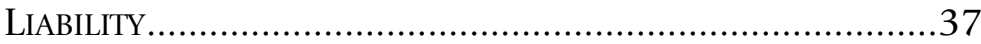

V. THE REACTION TO TRACEY V. SOlESKY ...................................43

VI. The State of the LaW Today: A New Policy Debate ............47

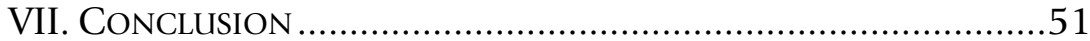

* Professor of Law, The John Marshall Law School. The author would like to thank Elizabeth Brusa and Victor Salas for their research assistance. 


\section{INTRODUCTION}

Just over two years ago, the Maryland Court of Appeals decided Tracey $v$. Solesky, in which it modified Maryland common law related to strict liability in cases involving injuries caused by dogs. ${ }^{1}$ In doing so, it fueled a debate on the best approach to manage the effects of these types of injuries. The response to the opinion was swift. Several bills that were intended to abrogate the effects of the decision were quickly presented in both the Maryland Senate and House of Representatives. ${ }^{2}$ However, the lawmakers were unable to come to an agreement on the best way to approach the issue. Their efforts continued over the next two years until last year when a bill was finally approved and signed into law. ${ }^{3}$

Although Solesky was neither a significant departure from the applicable law at the time nor an adoption of the alternative, more prevalent view in other jurisdictions, the action taken by the legislature abrogated its holding entirely. As a result, the current applicable doctrine is a collage of different approaches and it is difficult to see how it protects victims of dog attacks more than they were protected before Solesky. This Article will review the tort law doctrines that operate to regulate dog ownership and discuss the consequences of the newly approved statute.

\section{The Policy Debate Before Tracey V. SOLESKY}

With an estimated 73 million dogs in American households, it is fair to say that dogs are the most common household pets in the United States. ${ }^{4}$ In 2010, it was estimated that over 800,000 households in Maryland included a dog. ${ }^{5}$ Additionally, pit bulls are the second most popular type of dogs registered in the state. ${ }^{6}$ Although most of these pets are perfectly domesticated, about five million Americans experience a dog attack every year. ${ }^{7}$ Some of

1 Tracey v. Solesky, 50 A.3d 1075, 1079 (Md. 2012), superseded by statute, MD. Code ANN., CTs. \& Jud. Proc. § 3-1901 (West 2014).

2 See discussion infra Part V.

3 See Md. Code AnN., CTs. \& Jud. Proc. § 3-1901 (West 2014).

4 April Pruitt-Summers, Dog Bites Man: Liability for Dog Attacks Under the Animal Control Act, 96 ILL. B.J. 408, 408 (2008).

5 Errin K. Roby, Tort Liability Unleashed: Solesky v. Tracey and Landlord Duty to Third Parties, 43 U. BALT. L.F. 61, 61 (2012).

6 Interview with Frank Branch, representative of Maryland Votes for Animals, Discussion of Failure of Dog Bite Bill, WUSA9-TV (Aug. 15, 2012, 6:01 PM), http://www.wusa9.com/story/local/2012/08/15/3962053/.

7 Cynthia A. Mcneely \& Sarah A. Lindquist, Dangerous Dog Laws: Failing to Give Man's Best Friend A Fair Shake At Justice, 3 J. Animal L. 99, 99 (2006). 
these attacks result in death, and more than half of the victims of all attacks are children. ${ }^{8}$ For this reason, there is a long history of debates about the best policy approaches to deal with the issues raised by injuries caused by dogs. ${ }^{9}$

The vast majority of dog attack related deaths have been caused by pit bulls. ${ }^{10}$ Consequently, the most prevalent debate in recent years has centered on whether that specific dog breed should be treated differently through legislation and regulation. ${ }^{11}$ As a result, a number of jurisdictions have enacted breed-specific regulations, which, in turn, have generated litigation to challenge their validity. ${ }^{12}$

Adding to the debate, in 2012, the American Bar Association ("ABA") adopted a resolution urging legislative bodies and governmental agencies to adopt comprehensive breed-neutral dangerous dog laws that ensure due process protections for owners, encourage responsible pet ownership, and focus on the behavior of both dog owners and dogs. ${ }^{13}$ The resolution did not dispute that there is a need to regulate dog ownership due to the conduct of certain dogs or their owners, but it emphasized that the regulation should be fair and neutral. ${ }^{14}$

More importantly, however, the ABA explicitly took the position that breed-specific regulation has been the result of "panic

8 Id.

9 In Solesky, the court discusses some of the history of the early cases in Maryland, starting with the 1916 decision in Bachman v. Clark, 128 Md. 245 (1916), the first reported dog bite case involving a pit bull. See Tracey v. Solesky, 50 A.3d 1075, 107677 (2012), superseded by statute, MD. CODE ANN., CTs. \& JuD. Proc. § 3-1901 (West 2014).

10 According to a study by DogsBite.org, included in an amicus brief the organization filed in Tracey $v$. Solesky, between 2005 and 2010, pit bulls caused 105 deaths in the United States. Brief of Amicus Curiae Dogsbite.org in Support of Appellees at 14, Tracey v. Solesky, 50 A.3d 1075 (Md. 2012) (No. 53), 2011 WL 6409239 , at $* 14$. This number amounts to $58 \%$ of all deaths caused by dogs during those years. $I d$. at 14 . Rottweilers have the next highest number of deaths caused during this period with 25. Id. at 20. Thirteen of the fourteen Americans killed by dogs in the first five months of 2013, or 93 percent, were killed by pit bulls and pit bull mixes. Colleen Lynn, The Front Burner: Banning Pit Bulls Saves Lives and Protects the Innocent, THE ORLANDO SENTINEL (May 24, 2013), http://articles.orlandosentinel.com/ 2013-05-24/news/os-ed-front-burner-pit-bulls-pro-20130523_1_pit-bulls-viciousdogs-many-dogs.

11 The American Kennel Club and the American Dog Breeders Association currently recognize three lines of pit bull terriers. John Gibeaut, A Bite Worse Than Its Bark: Maryland Puts Pit-Bull Owners on Liability Notice, A.B.A. J. (Sep. 1, 2012), http://www.abajournal.com/magazine/article/a_bite_worse_than_its_bark_maryland _puts _ pit-bull_owners_on_liability_notic/.

12 See infra notes 53-55.

13 Am. Bar Ass'n, Resolution 100 (2012).

14 Id. 
policymaking" enacted out of emotion that often fails to consider the effects on the rights of responsible dog owners. ${ }^{15}$ In short, the ABA has decided to oppose breed-specific regulation, calling it discriminatory because it considers such laws to be inconsistent with traditional notions of due process. ${ }^{16}$

The report that accompanied the ABA's resolution suggested that, instead of adopting breed-specific regulation, jurisdictions should look for alternative ways to promote safety and responsible dog ownership. ${ }^{17}$ As an example, it cited the fact that, following a series of well publicized dog attack incidents, the Illinois Legislature enacted comprehensive, non-breed-specific, generic public safety measures that targeted reckless owners and aggressive dog behavior. $^{18}$

What the report does not mention is that legislation is not the only alternative when it comes to regulating conduct. Tort law doctrines also operate as forms of regulation. In fact, one of the applicable statutes in Illinois, the Animal Control Act, is based on the principle that civil liability for injuries caused by dogs should be based on a very strict theory of liability. ${ }^{19}$ Thus, while avoiding discrimination among breeds of dogs in regulation, the state is using its tort law doctrines to impose a very high level of indirect regulation. Not surprisingly, Illinois had the second highest total payouts and the largest number of dog bite insurance claims nationally in $2010 .^{20}$

15 Id. at 1

16 Id. at $2-7$.

17 Id. at $1-10$.

18 Id. at 9 .

19 Section 16 of the Illinois Animal Control Act states that "[i]f a dog or other animal, without provocation, attacks, attempts to attack, or injures any person who is peaceably conducting himself or herself in any place where he or she may lawfully be, the owner of such dog or other animal is liable in civil damages to such person for the full amount of the injury proximately caused thereby." 510 ILL. COMP. STAT. ANN. 5/16 (West 2006). If the elements of this section are met, the defendant would be liable even if the plaintiff does not show negligent conduct on the part of the defendant regarding whether the dog had exhibited dangerous propensities in the past or that the defendant knew or should have known of the dog's dangerous propensities. Janis $\mathrm{v}$. Graham, 946 N.E.2d 983 (Ill. App. Ct. 2011) (stating that one of the purposes of the Animal Control Act was to eliminate the common law requirement that an injured party must plead and prove that the animal owner knew or should have known about the animal's dangerous propensities); Docherty v. Sadler, 689 N.E.2d 332 (Ill. App. Ct. 1997) ("The purpose of the [Animal Control] Act was to eliminate the 'one-bite rule' which, at common law, required a plaintiff to plead and prove a dog owner either knew or was negligent in not knowing a dog had a propensity to injure people.").

20 See Erline Aguiluz, Illinois Ranks No. 2 in Dog Bite Claims, Says State Farm, ThE Chicago Personal Injury LAW Blog (May 12, 2011, 9:07 AM), 
A debate about the best regulatory approaches to manage the consequences of injuries caused by dogs would not be complete without a discussion of the effects of applicable civil liability doctrines. This is one of the reasons why Tracey $v$. Solesky is so important.

\section{BASIC PRINCIPLes Related to Civil Liability FOR INJURIES CAUSED BY DOGS}

At the time Tracey $v$. Solesky was decided, the common law doctrines applied in Maryland in cases involving injuries caused by dogs were based on traditional principles of tort law, which recognized possible claims based on negligence and strict liability if the plaintiff could show that the defendant knew or should have known of the vicious propensities of the dog in question. ${ }^{21}$

If the plaintiff chose to pursue the claim based on negligence, the plaintiff had to show that the defendant acted in a way that created an unreasonable risk of harm under circumstances where it was foreseeable that an injury could occur. ${ }^{22}$ In turn, to demonstrate

http://chicagopersonalinjurylegalblog.com/2011/05/illinois-ranks-no-2-in-dog-biteclaims-says-state-farm.html (citing a report released by State Farm Insurance Company). In Maryland, State Farm Insurance, the state's largest underwriter of homeowners insurance, paid out nearly $\$ 1.6$ million for fifty-one dog bite claims in 2012 -about $\$ 31,000$ per victim. Fredrick Kunkle, Md. Bill Would Make All Dog Owners Liable for an Attack Regardless of Breed, THE WASHINGTON POST (Mar. 24, 2014), available at http://www.washingtonpost.com/local/md-politics/md-law-would-make-all-dogowners-liable-for-an-attack-regardless-of-breed/2014/03/23/301eb210-b031-11e3a49e-76adc9210f19_story.html.

21 Slack v. Villari, 476 A.2d 227 (Md. Ct. Spec. App. 1984). Presumably, a plaintiff could also bring a claim based on an intentional tort; but there do not seem to be any reported cases. Cases based on an intentional tort theory for injuries caused by dogs are not common at least in part because of the real possibility that the intentional nature of the conduct would result in making insurance coverage unavailable. Litigating Animal LaW Disputes: A Complete Guide For lawyers 24-25 (Joan E. Schaffner \& Julie Fershtman eds., 2009) (homeowners insurance policies and commercial liability policies typically exclude coverage for intentional conduct).

22 Slack v. Villari, 476 A.2d 227 (Md. Ct. Spec. App. 1984) (stating that claimant must show that the owner exercised ineffective control of an animal in a situation where it would reasonably be expected that injury could occur, and injury does proximately result from the negligence); see also RESTATEMENT (SECOND) OF TORTS $\$ 518$ (1965); RESTATEMENT (THIRD) OFTORTS $\$ 23 \mathrm{cmt}$. i (2000). Examples of conduct that has been considered to be negligent under the circumstances include improper handling, keeping, restraining or training. See, e.g., Miller v. Anderson, 728 P.2d 407 (Kan. Ct. App. 1986) (failure to keep dog confined); Mech v. Hearst Corp., 496 A.2d 1099 (Md. Ct. Spec. App. 1985) (failure to close gate on property guarded by trained attack dog and failure to post warning signs); McAbee v. Daniel, 445 S.W.2d 917 (Tenn. Ct. App. 1968) (failure to keep child away from dog). In addition, in some cases, the violation of a specific statute enacted to protect the public from possible injuries can be considered to be evidence of negligence. Moore v. Myers, 868 A.2d 954 (Md. Ct. Spec. 
that the circumstances were such that a possible injury was foreseeable, the plaintiff would have to argue that something about the dog or its history would make a reasonably prudent person believe that precautions should have been taken to minimize the risk of such an injury. ${ }^{23}$ These principles have not changed.

In the end, the validity and possible success of a negligence claim hinges substantially on whether the evidence supports the conclusion that, given the circumstances, the conduct of the defendant should be considered negligent. Given the possible difficulties in obtaining the necessary evidence, it is more common for plaintiffs to choose to bring the claim based on strict liability principles.

In order to support a claim for strict liability, the plaintiff does not have to prove the defendant's specific conduct nor that the conduct should be considered negligent. ${ }^{24}$ There are, however, different approaches to what the plaintiff must prove. Before Tracey $v$. Solesky was decided, Maryland followed what can be called the "traditional" approach, which is reflected in Section 509 of the Second Restatement of Torts and Section 23 of the Third

App. 2005); Moura v. Randall, 705 A.2d 334 (Md. Ct. Spec. App. 1998). For a violation of a statute or ordinance to constitute evidence of negligence, the resulting injury must be proximately caused by the violation of the statute, the injury must be to a member of the class of people that the statute or ordinance was designed to protect, and the injury sustained must be of the type that the statute was intended to prevent. Gardenvillage Realty Corp. v. Russo, 366 A.2d 101 (Md. Ct. Spec. App. 1976).

23 Moura, 705 A.2d at 341 (indicating that the dog owner's knowledge of the propensities of the animal is relevant in determining the degree of control that a reasonable person would have exercised under the circumstances). Examples of the type of evidence used to support this element of the claim include proof that the dog had a well-known reputation of being ill-tempered, that the defendant had been told by others that the dog had attacked people in the past, that the defendant warned others to stay away from the dog, that the defendant took special precautions to keep the dog away from others, that the defendant kept the dog muzzled and, of course, that the defendant admitted that the dog was vicious or that the dog had attacked others in the past. Litigating ANimal LAW Disputes: A COMPlete Guide For LAWYERS, supra note 21, at 11. See, e.g., Matthews v. Amberwood Associates Ltd. Partnership, Inc., 719 A.2d 119 (Md. 1998) (knowledge imputed to defendant because employees had reported dog's aggressiveness and viciousness); Goode v. Martin, 57 Md. 606 (Md. 1882) (knowledge presumed because owner kept dog tied); Warwick v. Mulvey, 127 N.W.2d 433 (S.D. 1964) (defendant witnessed dog's prior assault on delivery person); Mills by Mills v. Smith, 673 P2d 117 (Kan. Ct. App. 1983) (complaints from neighbors about animal running loose); Richmond v. Knowles, 265 A.2d 53 (Del. Super. Ct. 1970) (defendant warned children, including plaintiff, to stay away from dog); Fontecchio v. Esposito, 485 N.Y.S.2d 113 (Sup. Ct. 1985) (dog habitually chained up inside enclosed yard); Russell v. Lepre, 470 N.Y.S.2d 430 (Sup. Ct. 1984) (dog was kept muzzled and locked in basement when visitors were present).

24 See generally, DAN DOBBS, THE LAW OF TORTS 941 (2d ed. 2011). 
Restatement. $^{25}$ According to this approach, the owner of a domesticated animal can be subject to liability for harm done by the animal if the owner knows or should know that the animal has abnormally dangerous propensities. ${ }^{26}$ This is true even if the owner has exercised the utmost care to prevent the animal from causing the harm. ${ }^{27}$ Likewise, a landlord who harbors a dangerous dog would be subject to the same liability. ${ }^{28}$

This traditional view is based on the premise that domesticated animals are presumed to be docile and not dangerous enough to justify the imposition of strict liability, which is a theory of liability reserved for cases where injuries are suffered under circumstances that pose high levels of risk. ${ }^{29}$ However, the traditional view also recognizes the reality that not all animals are the same and that some do create unreasonable, indeed, abnormally high, risks to others. In such cases, as explained in the Restatement, "[o]nce the

25 Restatement (THiRd) OFTORTS $\$ 23$ (2000); RestatemEnt (SECOND) OFTORTS $\$ 509$ (1965).

26 It is important to say that liability "can" be imposed, instead of "would" be imposed, because the defendant can raise valid defenses that can result in the dismissal of the claim. In Maryland, for example, it has been decided that assumption of the risk may be raised as a defense in a strict liability action for injuries caused by a dog. See Benton v. Aquarium, Inc., 489 A.2d 549 (Md. Ct. App. 1985). For a discussion of possible defenses applicable in strict liability cases, see LITIGATING ANIMAL LAW DisPUTES: A COMPlete Guide For LAWYers, supra note 21, at 20-24. See also Restatement (Third) OF TORTS $\$ 23 \mathrm{cmt}$. h (2000) (possible defense based on provocation).

27 REsTATEMENT (SECOND) OF TORTS $\$ 509$ (1965); REsTATEMENT (THIRD) OF TORTS: Liab. For Physical \& Emotional Harm $\$ 23$ (2000). Although the text of the Second Restatement does not explicitly say that the possible liability will be strict, it is clear that it is intended to be strict because evidence of the exercise of due care will not eliminate the possibility of liability as it would if the claim were for negligence. The more recently approved Third Restatement has changed the section's language to clarify that liability is strict; however, otherwise, the interpretation is the same as the interpretation of the Second Restatement's language. See also JOHN DIAMOND ET AL., UNDERSTANDING TORTS 250-51 (4th ed. 2010) ("Keepers of dogs, cats, horses, or other domestic animals are liable for injury caused by the animal only where the possessor knew or should have known of the animal's aggressive disposition."). Maryland cases holding that the plaintiff must show the defendant knew or should have known that the animal had dangerous propensities include Bachman v. Clark, 97 A. 440 (Md. 1916); Finneran v. Wood, 241 A.2d 579 (Md. 1968); Twigg v. Ryland, 62 Md. 380 (Md. 1884); Mazur v. Scavone, 378 A.2d 1355 (Md. Ct. Spec. App. 1977); Mech v. Hearst Corp., 496 A.2d 1099 (Md. Ct. Spec. App. 1985); Slack v. Villari, 476 A.2d 227 (Md. Ct. Spec. App. 1984).

28 Restatement (SECOND) OF TORTS $\$ 514$ (1965).

29 The Third Restatement explains this view by using a "cost-benefit analysis" comparing the important benefits domesticated animals contribute to those who own them with the "modest level of danger" created by their ownership. RESTATEMENT (ThiRD) OF TORTS: Liab. FOR Physical \& EMOTIONAL HARM $\$ 23 \mathrm{cmt}$. b (2000). Based on this analysis, it concludes that there is little support for applying the principles of strict liability in cases of injuries caused by "such ordinary animals." 
owner or possessor of such an animal knows or has reason to know of such a danger, strict liability, subject to limitations and defenses, becomes appropriate." 30

In jurisdictions that follow this traditional common law approach, the big issue is whether the evidence available is sufficient to prove that the dog has vicious tendencies and that the defendant knew or should have known about the dangerous propensities of the dog in question. ${ }^{31}$ Although the vicious tendencies of the animal and the defendant's knowledge can be inferred from surrounding circumstances, it is still incumbent upon the plaintiff to prove both and it is not always easy to do. ${ }^{32}$

For this reason, most jurisdictions have adopted a second approach to strict liability in cases related to injuries caused by dogs, which does not require the plaintiff to show that the defendant had knowledge of the dangerous propensities of the dog. ${ }^{33}$ However, because the vast majority of jurisdictions that have eliminated the plaintiff's need to prove knowledge have done so in cases that involved injuries caused by dogs, those jurisdictions in essence have created a separate doctrine that applies to dogs only. In these jurisdictions, if the injury is caused by a dog, the scienter requirement is eliminated and the plaintiff would not have to prove knowledge of the vicious propensities of the animal. However, if the injury was caused by any other type of domesticated animal, the scienter requirement would still apply. According to the Department of Legislative Services of the Maryland General Assembly, thirty-two states have adopted this approach. ${ }^{34}$

30 Restatement (Third) OF TORTS: Liab. FOR PhysicAl And EMOTIONAL Harm $\$ 23 \mathrm{cmt}$. b (2000). See also Restatement (SECOND) OF TORTS $\$ 509 \mathrm{cmts}$. d, e (1965) (finding there is no social value in keeping animals that are vicious or have other dangerous propensities that are in excess of those necessary for their utility and are abnormal to their class).

31 DоввS, supra note 24, at 945-47. See also Dog Owner Liability, Dog LAW (last visited Jan. 5, 2015), http://doglaw.hugpug.com/doglaw_081.html.

32 Restatement (SECOND) OF TORTS $\$ 509 \mathrm{cmt}$. g (1965) (stating that it is not necessary to show that possessor knows or should know that dog has attacked someone in the past and that it is sufficient to show knowledge that dog has exhibited a tendency to attack). See supra note 23 for examples of the type of evidence that can be used to support a claim that the defendant knew or should have known of the vicious propensities of a dog.

33 DоввS, supra note 24, at 947; Dog Owner Liability, Dog LAW (last visited Jan. 5, 2015), http://doglaw.hugpug.com/doglaw_081.html. See also supra note 19; MD. GeN. Assemb. DeP'T Of Legis. SeRvs., FisCAL AND POLICY Note, S.B. 247, 2014 Sess., at 4 (2014), available at http://mgaleg.maryland.gov/2014RS/ fnotes/bil_0007/sb0247.pdf.

34 MD. Gen. Assemb. Dep'T of Legis. Servs., Fiscal and Policy Note, H.B. 73, 2014 Sess., at 3-4 (2014), available at http://mgaleg.maryland.gov/2014RS/fnotes/ 
Interestingly, however, the Restatement (Third) rejects this approach because it cannot justify imposing a different rule simply because the animal involved is a dog as opposed to any other type of domesticated animal. ${ }^{35}$

\section{Tracey V. Solesky: A Third Possible Approach to Strict Liability}

In Tracey $v$. Solesky, the Court of Appeals of Maryland had the option to apply the existing common law at the time or to follow the approach adopted by a majority of jurisdictions. Instead, however, the court decided to retain the basis of the common law approach and modify one of its elements, thus creating a new approach to the question.

The facts in Solesky were not in dispute. ${ }^{36}$ During the course of one day, a pit bull attacked two boys in separate incidents. ${ }^{37}$ The dog almost killed the second boy. As a result, the boy had to undergo five hours of surgery, after which he spent seventeen days in the hospital, suffered through additional surgeries, and spent a year in rehabilitation. ${ }^{38}$ There was no question that the injuries were caused by the dog, nor that the injuries were extremely severe. ${ }^{39}$ Eventually, the boy sued the owner of the dog and his landlord

bil_0003/hb0073.pdf; MD. Gen. Assemb. Dep't Of Legis. Servs., Fiscal and Policy Note, S.B. 247, 2014 Sess., at 3-4 (2014), available at http://mgaleg.maryland.gov/2014RS/ fnotes/bil_0007/sb0247.pdf (These states are Alabama, Arizona, California, Colorado, Connecticut, Delaware, Florida, Georgia, Illinois, Indiana, Iowa, Kentucky, Louisiana, Maine, Massachusetts, Michigan, Minnesota, Missouri, Montana, Nebraska, New Hampshire, New Jersey, Ohio, Oklahoma, Pennsylvania, Rhode Island, South Carolina, Tennessee, Utah, Washington, West Virginia, and Wisconsin). See also RESTATEMENT (THIRD) OF TORTS $\$ 23$ (2000); Mascola v. Mascola, 168 N.J. Super. 122, 127 (App. Div. 1979) (The New Jersey statute eliminates the requirement that a plaintiff prove that the dog owner knew or should have known of the dog's vicious tendencies); Janis v. Graham, 946 N.E.2d 983, 987 (Ill. App. Ct. 2011) ("[O]ne of the purposes of the Animal Control Act was to 'eliminate the common law requirement that an injured party must ... prove that the animal owner knew or should have known about the animal's dangerous propensities.'") (citing Beggs v. Griffith, 913 N.E.2d 1230, 1235 (2009)); In re Persechino, 423 B.R. 1 (Bankr. D. Conn. 2010) (stating that the purpose of the Connecticut dog bite statute is to "abrogate commonlaw doctrine of scienter as applied to damages by dogs to persons and property .... ").

35 REsTATEMENT (THIRD) OF TORTS $§ 23$ (2000) ("For common-law purposes, categorical distinction between dogs and all other animals is not justifiable .... To impose strict liability, without regard to knowledge on the part of the defendant is also difficult to justify.").

36 See Tracey v. Solesky, 50 A.3d 1075, 1078 (Md. 2012), superseded by statute, MD. Code AnN., CTS. \& Jud. Proc. \$ 3-1901 (West 2014).

37 Id.

38 Id.

39 Id. 
arguing both negligence and strict liability. ${ }^{40}$ The trial court granted a judgment for the defendant-landlord on the negligence claim on the grounds that there was no evidence of negligent conduct. An intermediate court of appeals reversed and the landlord appealed. ${ }^{41}$

In his appeal, the landlord raised a number of questions, the most important of which related to the validity of the strict liability claim. ${ }^{42}$ However, because the question was not accurately phrased, the court went on to address a different, and more relevant, issue. ${ }^{43}$ That issue was whether proof of a dog's breed, by itself, is enough to prove that specific dog's dangerous nature and, therefore, whether proof of the defendant's knowledge of the dog's breed is enough to prove the defendant's knowledge of the specific dog's dangerous propensity. ${ }^{44}$

At the time, the predominant view in Maryland, and in most of the United States, was that proof of a dog's breed alone would not suffice to establish that a particular dog had dangerous propensities. ${ }^{45}$ However, based on its conclusion that there is now enough information to support the view that pit bulls are inherently dangerous, the court adopted a different view and remanded the

\footnotetext{
$40 \quad I d$.

$41 \quad$ Id.

42 Tracey v. Solesky, 50 A.3d 1075, 1078-79 (Md. 2012), superseded by statute, MD. Code ANN., CTS. \& Jud. Proc. § 3-1901 (West 2014).

43 The question presented by the appellant was whether the "harboring of American Staffordshire Terriers (more commonly known as "pit bulls") by tenants [should be considered] an inherently dangerous activity for which landlords could be held strictly liable." Tracey, 50 A.3d at 1078. The problem with the appellant's formulation of the question is that it references the doctrine of "inherently dangerous activities" as the basis for the imposition of strict liability, which is a different doctrine than the one relevant to the case. Typically, the analysis of a case asking whether an activity is inherently dangerous so as to justify the imposition of strict liability is resolved by applying the factors discussed in $\$ 520$ of the Restatement (Second) of Torts. However, these factors are not relevant to the determination of whether the owner of a domesticated animal should be held strictly liable for injuries caused by the animal and the common law applicable at the time was not based on an analysis of what constitutes an inherently dangerous activity.

44 Tracey, 50 A.3d at 1079.

45 Moura v. Randall, 705 A.2d 334, 344 (Md. Ct. Spec. App. 1998) (stating that the fact that the dog was a rottweiller "was not sufficient to establish that he was vicious" for purposes of the strict liability claim); Slack v. Villari, 476 A.2d 227, 235 (Md. Ct. Spec. App. 1984) (noting that the fact that the dog was a doberman pinscher was not evidence of the dog's dangerous propensity); Lundy v. California Realty, 216 Cal. Rptr. 575, 580 (Cal. Dist. Ct. App. 1985) (stating that the fact that dog was a German Shepherd was not relevant to determining whether it had dangerous propensities); Eason v. Miller, 265 S.E.2d 340, 341 (Ga. 1980) (noting that breed alone is no indication of dangerous propensity).
} 
case to be decided under a newly created standard. ${ }^{46}$

The new standard adopted by the court still requires the plaintiff to prove that the defendant knew or should have known of the dangerous propensities of the dog; but it is based on essentially the opposite premise of the traditional common law view. Whereas the traditional view starts from the premise that dogs are inherently docile, the standard adopted by the court in Solesky starts from the premise that pit bulls have inherent vicious propensities. In turn, once it is determined that pit bulls have inherent vicious propensities, it follows that, if the defendant knows or should know that the dog is a pit bull, the defendant knows or should know that it has vicious propensities. For this reason, according to the court's new approach, a plaintiff could establish the necessary knowledge to justify the imposition of strict liability if the plaintiff simply shows that the defendant knew or should have known that the dog in question was a pit bull. ${ }^{47}$

Needless to say, the consequences of the court's ruling were significant. As the court explained, by adopting the new approach, the court modified the elements of a cause of action based on strict liability for cases involving pit bulls. ${ }^{48}$ A plaintiff would no longer

46 The court supported this conclusion by citing its own comments in Matthews v. Amberwood Assoc. Ltd. P'ship, Inc., 351 Md. 544 (1998), other courts' similar conclusions, and published articles and reports from the Albuquerque Humane Society, The American Veterinary Medical Association, the Annals of Surgery, and the Center for Disease Control. These sources suggested in one way or another that pit bulls are more dangerous than other breeds either because they cause more injuries, or because the injuries they cause are more severe. Matthews, $351 \mathrm{Md}$. at 563 n.4. For instance, in Matthews, a negligence case, the court concluded that injuries by a pit bull were foreseeable due to pit bulls' "extreme dangerousness" and their greater propensity to bite humans. Id. at 562-63.

47 Specifically, the court stated:

We hold that upon a plaintiff's sufficient proof that a dog involved in an attack is a pit bull or a pit bull mix, and that the owner, or other person(s) who has the right to control the pit bull's presence on the subject premises (including a landlord who has the right and/or opportunity to prohibit such dogs on leased premises as in this case) knows, or has reason to know, that the dog is a pit bull or cross-bred pit bull mix, that person is strictly liable for the damages caused to a plaintiff who is attacked by the dog on or from the owner's or lessor's premises.

Solesky, 50 A.3d at 1089. However, after a motion for reconsideration, the court limited the ruling to pure pit bulls, eliminating the references to pit bull "mixes." Id. at 109698.

48 Solesky, 50 A.3d at 1079. It should be noted that the dissenting judges overstate the consequences of the decision when they write that " $[\mathrm{i}] \mathrm{n}$ the words of the majority, the owner or landlord will be held strictly liable for any harm the dog causes" if the plaintiff meets the new requirements. Id. at 1090 (Greene, J., dissenting). This statement suggests that the holding creates absolute liability in cases involving pit bulls, 
have to prove that the specific dog involved in the case had vicious propensities, nor that the defendant knew of those propensities. ${ }^{49}$ The plaintiff would only have to prove that the dog was a pit bull and that the defendant knew or should have known the dog was of such a breed. ${ }^{50}$ If the defendant is a landlord, the plaintiff would then also have to show that the defendant knew or should have known of the presence of the dog on the leased premises and that the defendant had the right or opportunity to prohibit dogs on the leased property. ${ }^{51}$

Second, the new standard would apply only to one specific breed of dogs, which is an unpopular and controversial approach to handling the problem of injuries caused by dogs. As stated above, the Restatement Third rejects the notion of creating a standard of strict liability that differentiates dogs from other domestic animals, so it would be safe to assume that it would reject a new approach which isolates a specific breed. Also, the new approach can be criticized for the same reasons that the ABA explicitly rejected the notion of breed-specific regulation. It could be argued that it is another example of "panic policymaking" or the result of poorly informed emotion that failed to consider the effects on the rights of responsible dog owners. ${ }^{52}$

Third, although the ruling in the case relates to strict liability, the reasoning behind it would make it easier for plaintiffs in negligence cases to support the element of proximate cause. If it is the law in the jurisdiction that pit bulls are inherently dangerous, then it can be argued that it is reasonably foreseeable that all pit bulls can cause injury to someone.

Finally, the new approach would put pit bull owners in the difficult position of having to take the risk of possible strict liability

which is an incorrect reading of the decision.

49 Tracey v. Solesky, 50 A.3d 1075, 1079-80 (Md. 2012), superseded by statute, MD. Code ANN., CTS. \& Jud. Proc. § 3-1901 (West 2014).

50 Id.

$51 \quad$ Id. at 1089.

52 The dissenting opinion in Solesky also complained that the court reached its conclusions about pit bulls without the benefit of expert evidence. Id. at 1090 (Greene, J., dissenting). Others have challenged similar conclusions. See, e.g., Rose Eveleth, Owners, Not Breeds, Predict Whether Dogs Will Be Aggressive, SMITHSONIAN Mag. (March 4, 2014), http://www.smithsonianmag.com/smart-news/owners-not-breeds-predictwhether-dog-will-be-aggressive-180949962/?no-ist (reporting on Rachel A. Casey et al., Human Directed Aggression in Domestic Dogs (Canis Familiaris): Occurrence in Different Contexts and Risk Factors, 152 Applied ANIMAL BeHAVIOUR SCIENCE 52, 52-63 (2014), available at http://www.appliedanimalbehaviour.com/article/S0168-1591(13) 00292-X/abstract. 
or give up their family pet. Under the circumstances, there is nothing a dog owner could do in advance to prevent liability if a pet pit bull with absolutely no history of violent behavior suddenly bites a person without provocation. Other than giving up the dog, the only thing to do would be to obtain insurance to cover possible liability, which is sometimes difficult to do. ${ }^{53}$ And, given that the new approach would make it easier for plaintiffs to support both strict liability and negligence claims, pit bull owners' insurance carriers might increase rates or limit coverage.

On the other hand, the opinion can be defended against the criticism. First, although breed-specific regulation is controversial and disfavored by the ABA, it is not uncommon and has been validated by courts. ${ }^{54}$ There is even one Maryland County that has prohibited pit bull ownership. ${ }^{55}$ Also, breed-specific regulation has proven to be popular with the general public. ${ }^{56}$ More importantly, Solesky was not the first court opinion to hold that a dog's breed can

53 See Arin Greenwood, Pit Bull Owners Find That Good Dogs Face Bad Insurance Policies, Huffington POST (Mar. 3, 2014), http://www.huffingtonpost.com/2014/ 03/03/pit-bulls-insurance_n_4869750.html (discussing how difficult it can be to obtain insurance to cover possible liability for injuries caused by a pit bull). This argument may not be as strong in Maryland, however. According to the Department of Legislative Services of the Maryland General Assembly, only three of the top ten insurers who provide homeowners insurance in the state have exclusions or limits on coverage for injuries caused by pit bulls. MD. GEN. ASSEMB. DeP'T OF LEGIS. SERVS., FISCAL AND POlicy Note, H.B. 73, 2014 Sess. (2014), available at http://mgaleg.maryland.gov/ 2014RS/fnotes/bil_0003/hb0073.pdf; MD. GEN. AsSEMB. DEP'T OF LeGIS. SERVS., FISCAL AND POLICY NOTE, S.B. 247, 2014 Sess. (2014), available at http://mgaleg.maryland.gov/ 2014RS/fnotes/bil_0007/sb0247.pdf.

54 See City of Toledo v. Tellings, 871 N.E.2d 1152, 1157 (Ohio 2007) (explaining that the state has a legitimate interest in protecting citizens from the dangers posed by pit bulls); McNeely v. United States, 874 A.2d 371, 391 (D.C. 2005); Colorado Dog Fanciers, Inc. v. City \& Cnty. of Denver, 820 P.2d 644, 650 (Colo. 1991); Garcia v. Vill. of Tijeras, 767 P.2d 355, 360-61 (N.M. Ct. App. 1988). See also Nathan Bass, Wayne County Town's Pit Bull Ban Upheld, The West Virginia ReCord (Jan. 24, 2013, 4:00 AM), available at http://wvrecord.com/news/s-3962-state-supreme-court/257257-waynecounty-towns-pit-bull-ban-upheld (reporting that the Supreme Court of West Virginia affirmed the constitutionality of the Town of Ceredo's ordinance prohibiting the ownership of pit bull terriers within the city limits).

55 Prince George's County prohibits owning, keeping, or harboring pit bull terriers. PRinCE GeORGE's CNTY., MD., CODE $\$ 3.185 .01$ (Supp. 2010).

56 In August of 2012, a strong campaign to repeal the ban on pit bulls in MiamiDade County, Florida failed when voters decided to retain it by a wide margin. See Christina Hernandez, Julia Bagg \& Willard Shepard, Miami-Dade Residents Vote to Keep Pit Bull Ban Tuesday, NBC (Aug. 13, 2012, 11:31 PM), http://www.nbcmiami.com/ news/local/Miami-Dade-Residents-Vote-on-Pit-Bull-Ban-Repeal-Tuesday-166056926. html; see also Tazi Phillips, Update: Miami Votes To Keep Pit Bull Ban, Global ANimaL (Aug. 15, 2012), http://www.globalanimal.org/2012/08/15/miami-votes-to-repealpit-bull-ban/79898/. 
be used to prove that a certain dog has vicious propensities. ${ }^{57}$ In 2003, for example, the Indiana Supreme Court held that,

[even if] there is no evidence of an owner's actual knowledge that his or her dog has dangerous propensities, the owner may nonetheless be held liable provided there is evidence that the particular breed to which the dog belongs has dangerous propensities. And this is so even where the owner's dog has never before attacked or bitten anyone .... In essence, a jury may not infer that an owner knew or should have known of a dog's dangerous or vicious propensities from the fact of a first time, unprovoked biting. Rather, in such an instance, a jury may infer that the owner knew or should have known of the dog's dangerous or vicious propensities only where evidence shows that the particular breed to which the owner's dog belongs is known to exhibit such tendencies. ${ }^{58}$

Second, if the jurisdiction is going to impose strict liability while requiring the plaintiff to show knowledge of the risk that the defendant creates by owning a dog, it seems logical and fair to allow the plaintiff to use all available evidence to support that claim. If there is evidence available that shows that a certain breed is known to be vicious, then the plaintiff should be allowed to use that evidence. ${ }^{59}$

Third, although the decision in Solesky does have the effect of instituting a breed-specific regulation, it does not ban pit bulls. It simply places pit bull owners and their landlords on notice that keeping a pit bull creates certain risks for which they need to be ready. Although they may not be able to completely eliminate those risks, owners and landlords can manage them by obtaining insurance and taking other necessary precautions to avoid possible injuries. Given the risks involved, the additional cost related to insurance is just part of the overall cost of dog ownership or of leasing properties to dog owners. Consistent with the principles behind the notion of strict liability, the opinion thus places the

57 See Poznanski v. Horvath, 788 N.E.2d 1255, 1259 (Ind. 2003); Thomas v. Weddle, 605 S.E.2d 244, 247 (N.C. Ct. App. 2004) (citing Griner v. Smith, 259 S.E.2d 383, 388 (N.C. Ct. App. 1979)) (stating that knowledge of the danger posed by the dog's breed is imputed to the defendant, regardless of the character or temperament of the individual animal); Radoff v. Hunter, 323 P.2d 202 (Cal. Ct. App. 1958) (indicating that the breed of dog may be considered in determining whether dog had dangerous propensities); Hood v. Hagler, 606 P.2d 548, 552-53 (Okla. 1979) (noting that the fact that the dog was part German Shepherd was considered relevant to finding that the dog had vicious tendencies); Thompson v. Wold, 289 P.2d 712, 715 (Wash. 1955) (stating that the breed of dog is relevant to the question of whether the dog has dangerous propensities).

58 Poznanski, 788 N.E.2d at 1259-60.

59 It is possible that the dissenting judges in Solesky would agree with this position. One of the reasons why they disagreed with the majority opinion was that the court reached its conclusions about pit bulls without the benefit of expert evidence. Solesky, 50 A.3d at 1090 (Greene, J., dissenting). See also supra note 48. 
possible responsibility for injuries upon those who are in a better position to protect against the risks involved and to manage the cost of injuries. ${ }^{60}$

\section{The ReAction to TRACEY V. SOLESKY}

Even though there is a strong argument that Solesky's approach to the application of strict liability in cases involving injuries caused by dogs was based on sound public policy, it quickly became very controversial. According to the Fiscal and Policy Notes of the House and Senate bills that eventually became the recently adopted statute, the decision in Solesky "drew criticism from dog owners, animal advocacy groups, landlords, and insurers as news reports emerged relating to landlords banning pit bulls and animal shelters preparing for an influx of pit bulls." 61 Some reported that the decision triggered a sharp increase in the number of pit bulls sent to shelters, as landlords began requiring that tenants move out or get rid of their pit bulls. ${ }^{62}$

In turn, as the ABA Journal reported, "pit bull owners and their advocates pressed the alarm button" and persuaded state legislators to work on enacting a bill to override the decision. ${ }^{63}$ Organizations such as the American Society for the Prevention of Cruelty to Animals, Best Friends Animal Society, and the Humane Society of the United States became active in the debate, holding rallies, issuing news releases, and testifying at hearings. ${ }^{64}$ However, the negative reactions to the opinion were not all about the same issues, and the differences of opinion became problematic as the legislature tried to propose a bill to abrogate the decision.

The efforts to abrogate the holding in Solesky started in May 2012, barely a month after the decision was issued, when the Maryland legislature called a special session to reconcile the state budget. ${ }^{65}$ The first round of bills drafted were ignored, however, as

60 Tracey v. Solesky, 50 A.3d 1075, 1088 (Md. 2012), superseded by statute, MD. Code ANN., CTS. \& JUD. Proc. \$ 3-1901 (West 2014).

61 MD. Gen. Assemb. Dep't of Legis. Servs., Fiscal and Policy Note, H.B. 73, 2014 Sess., at 3 (2014), available at http://mgaleg.maryland.gov/2014RS/fnotes/bil_0003/ hb0073.pdf; MD. Gen. Assemb. DeP'T Of Legis. SeRvs., FisCAl AND POliCy Note, S.B. 247, 2014 Sess., at 3 (2014), available at http://mgaleg.maryland.gov/2014RS/fnotes/ bil_0007/sb0247.pdf.

62 Kunkle, supra note 20.

63 Gibeaut, supra note 11.

64 Kunkle, supra note 20.

65 Maryland Legislature Mutes Landmark Ruling, Tracey v. Solesky, During 2014 Legislative Session, DogsBite Blog (June 2, 2014), http://blog.dogsbite.org/2014/06/ 
the legislative session was dedicated entirely to state financing issues. ${ }^{66}$ Instead, at the end of May, the House and Senate formed a ten member joint task force to study Solesky's impact and to make recommendations on legislation. ${ }^{67}$

At the task force hearings, critics of the decision in Solesky raised concerns over the following: (1) the notion of imposing strict liability on a dog owner based on breed-specific standards; (2) the lack of guidance as to what constitutes a pit bull; and (3) the negative effects on the housing rental market. ${ }^{68}$ The task force did not propose a bill, but, as a result of its work, bills to abrogate the decision in Solesky were introduced in both the House and Senate in August 2012, when the legislature called a second special session to discuss issues related to gambling regulation. ${ }^{69}$ However, the bills did not generate enough support and failed to be enacted into law. ${ }^{70}$

The Senate's bill, which was introduced first, essentially adopted what is now the majority approach in the United States. ${ }^{71}$ Subject to a few exceptions, it endorsed the imposition of strict liability for dog owners even in the absence of evidence of previous incidents involving the dog in question. ${ }^{72}$ For landlords, it adopted the traditional approach which would require the plaintiff to show the landlord knew of the dangerous propensity of the dog and of

maryland-legislature-mutes-landmark-ruling-tracey-v-solesky.html. See also, MD. GEN. Assemb. Dep'T Of Legis. Servs., FisCAl And Policy Note, S.B. 247, 2014 Sess., at 3 (2014), available at http://mgaleg.maryland.gov/2014RS/fnotes/bil_0007/sb0247.pdf.

66 Id.

67 See Md. Lawmakers Form Pit Bull Task Force, CBS BALTimORE (May 30, 2012), http://baltimore.cbslocal.com/2012/05/30/md-lawmakers-form-pit-bull-task-force/.

68 Md. Gen. Assemb. Dep't of Legis. Servs., Fiscal and Policy Note, H.B. 73, 2014 Sess., at 3 (2014), available at http://mgaleg.maryland.gov/2014RS/fnotes/ bil_0003/hb0073.pdf; MD. Gen. Assemb. Dep'T OF Legis. SERvS., FisCAL AND POlicy Note, S.B. 247, 2014 Sess., at 3 (2014), available at http://mgaleg.maryland.gov/2014RS/ fnotes/bil_0007/sb0247.pdf.

69 See supra note 68. See also Maryland Legislature Mutes Landmark Ruling, Tracey $v$. Solesky, During 2014 Legislative Session, DogsBite Blog (June 2, 2014), http://blog.dogsbite.org/2014/06/maryland-legislature-mutes-landmark-ruling-tracey -v-solesky.html; Susan Rappaport et al., Pit Bulls: Maryland's Solesky Case Changes Liability Standard, 44 U. BALT. L.F. 60, 61-62 (2013).

70 See supra note 69.

71 Md. Gen. Assemb. Dep't of Legis. Servs., Fiscal and Policy Note, S.B. 247, 2014 Sess. (2014), available at http://mgaleg.maryland.gov/2014RS/fnotes/bil_0007/ sb0247.pdf. See also Anthony Solesky, Father of Pit Bull Mauling Victim, to Testify at Hearings, DogsBiTE.ORG (Aug. 15, 2012), http://blog.dogsbite.org/2012/08/anthonysolesky-father-of-pit-bull.html.

72 Md. Gen. Assemb. DeP'T of Legis. Servs., Fiscal and Policy Note, S.B. 247, 2014 Sess. (2014), available at http://mgaleg.maryland.gov/2014RS/fnotes/bil_0007/ sb0247.pdf. 
the presence of the dog on the premises. ${ }^{73}$ In contrast, the House version of the bill proposed the imposition of strict liability only for dog owners whose dogs caused injuries while "at large" and would have eliminated liability altogether if a defendant could show contributory negligence on the part of the plaintiff. ${ }^{74}$ The House version of the bill was, therefore, incompatible with the version of the Senate and the legislators found it impossible to reconcile their differences. ${ }^{75}$

From there, during regular legislative session between January and April 2013, the House and the Senate attempted to compromise by designing bills that eliminated much of their original ideas. ${ }^{76}$ The Senate and the House abandoned their preferred approach and drafted compromise bills based on a completely new approach. Under the new bills, a dog attack would give rise to a rebuttable presumption of knowledge, on the part of the owner, that the dog had vicious propensities. ${ }^{77}$ The House approved one bill, which received a hearing in the Senate Judicial Proceedings Committee, but no further action was taken. ${ }^{78}$ An equivalent bill proffered by

73 Id.

74 H.B. 73, 2014 Leg., Reg. Sess. (Md. 2014) (introduced Jan. 8, 2014).

75 For a short video of an interview with Senator Jamie Raskin on why the attempt to approve a bill failed, see supra note 6 .

76 S.B. 160, 2013 Leg (Md. 2013); H.B. 78, 2013 Leg (Md. 2013). See also Summary of House and Senate Hearings, DOGsBITE BLOG (Feb. 7, 2013), http://www.dogsbite.org/media/maryland/senate-hearing-feb-2013.mp3 (testimony of the Solesky family during a hearing before the Senate on February 5, 2013); Colleen Lynn, Written Testimony by DogsBite.org: Opposition to Senate Bill 160, DoGsBITE.ORG (Feb. 5, 2013), http://www.dogsbite.org/pdf/written-testimony-dogsbite-senatecommittee-02052012.pdf (testimony of DogsBite.org during a hearing before the Senate on February 5, 2013).

77 S.B. 160, 2013 Leg., Reg. Sess. (Md. 2013) (establishing that, in an action against an owner of a dog for damages for personal injury or death caused by the dog, evidence that the dog caused the injury or death creates a rebuttable presumption that the owner knew or should have known that the dog had vicious or dangerous propensitiesproviding that the presumption may not be rebutted as a matter of law, but that the presumption may be rebutted by specified clear and convincing evidence); H.B. 78, 2013 Leg., Reg. Sess. (Md. 2013) (establishing that, in an action against a dog owner for damages for personal injury or death caused by the dog, evidence that the dog caused the injury or death creates a rebuttable presumption that the owner knew or should have known that the dog had vicious or dangerous propensities); Id. (stating that, in an action against a person other than an owner of a dog for specified damages, the common law prior to April 1, 2012, is retained as to the person without regard to the breed or heritage of the dog).

78 Md. Gen. Assemb. Dep't of Legis. Servs., Fiscal and Policy Note, H.B. 73, 2014 Sess., at 3 (2014), available at http://mgaleg.maryland.gov/2014RS/fnotes/bil_0003/ hb0073.pdf; Md. Gen. Assemb. DeP'T Of Legis. Servs., Fiscal and Policy Note, S.B.. 247, 2014 Sess., at 7 (2014), available at http://mgaleg.maryland.gov/2014RS/fnotes/ bil_0007/sb0247.pdf. 
the Senate and accompanied by a conference committee report initially passed both houses, but failed to pass a third reading in the House before the end of the 2013 legislative session. ${ }^{79}$

Reportedly, the attempt to enact the bills failed because the legislators could not agree on the level of proof needed by a defendant to rebut the presumption of knowledge of a dog's propensity to bite. The House bill required only a "preponderance of evidence." When the Senate amended the bill and raised the threshold to "clear and convincing evidence" in cases involving children, the House refused to agree to the change, and, once again, the bill failed to move forward. ${ }^{80}$

When the regular legislative session opened in 2014, new rebuttable presumption bills were introduced in both chambers. ${ }^{81}$ In yet another attempt to compromise, the new bill avoided the issue of the level of proof needed by including a new section meant to guarantee that the issue of whether the presumption is rebutted would be left to the jury. ${ }^{82}$ An accompanying bill in the House also retained the strict liability approach for cases in which the injuries were caused by dogs that were "at large." ${ }^{83}$ After holding hearings, which included testimony from the Solesky family and a failed attempt by members of the Senate to amend the bill back to the strict liability approach they had approved in 2012, the Senate approved a bill mirroring the two approved by the House. ${ }^{84}$ Finally, once both houses reconciled and approved a bill that included the rebuttable presumption approach, abrogated the decision in Solesky as to landlords, and recognized potential strict liability for injuries

\footnotetext{
79 See supra note 78.

80 See Colleen Lynn, Maryland High Court Ruling Stands: Pit Bulls are 'Inherently Dangerous', DogsBite BLOG (Apr. 17, 2013), http://blog.dogsbite.org/2013/04/ maryland-high-court-ruling-stands-pit-bulls-are-inherently-dangerous.html.

81 See H.B. 73, 2014 Leg., Reg. Sess. (Md. 2014) (introduced Jan. 8, 2014), available at http://mgaleg.maryland.gov/2014RS/bills/hb/hb0073f.pdf ; S.B. 247, 2014 Leg., Reg. Sess. (Md. 2014) (introduced Jan. 17, 2014), available at http://mgaleg.maryland.gov/2014RS/bills/sb/sb0247f.pdf.

82 See H.B. 73, 2014 Leg., Reg. Sess. (Md. 2014) (introduced Jan. 8, 2014), available at http://mgaleg.maryland.gov/2014RS/bills/hb/hb0073f.pdf ; S.B. 247, 2014 Leg., Reg. Sess. (Md. 2014) (introduced Jan. 17, 2014), available at http://mgaleg.maryland.gov/2014RS/bills/sb/sb0247f.pdf.

83 See H.B. 80, 2014 Leg., Reg. Sess. (Md. 2014) (introduced Jan. 8, 2014), available at http://mgaleg.maryland.gov/2014RS/bills/hb/hb0073f.pdf.

84 For parts of the testimony before a Senate hearing on the bill, see Summary of House and Senate Hearings, DoGSBITE.ORG (Feb. 7, 2013), http://www.dogsbite.org/ media/maryland/senate-hearing-feb-2014.mp3. Written Testimony by DogsBite.org: Opposition to Senate Bill 247, DogsBiTE.ORG (Feb. 6, 2014), http://www.dogsbite.org/ pdf/dogsbite-testimony-senate-02-06-2014-online-release.pdf.
} 
caused by dogs "at large," the bill was signed into law by Governor Martin O'Malley in April 2014. ${ }^{85}$

\section{The State of the LaW Today: A New Policy Debate}

Two years after Solesky, the law is different but the debate remains the same. What is the best policy approach for handling the costs of injuries caused by dogs? Who should be responsible, and how should that responsibility be determined? Which approach of the many available serves the best interests of those affected?

As discussed above, jurisdictions looking to decide how to approach claims of liability for injuries caused by dogs have several different options to choose from. First, there is the traditional approach that requires the plaintiff to show that the defendant knew or should have known of the dog's dangerous propensitieswhether in support of a negligence or a strict liability cause of action. Second, there is the more prevalent strict liability approach, which exempts the plaintiff from proving this type of knowledge and, subject to a few exceptions and defenses, can result in liability even if the defendant was not negligent and the dog had never caused trouble in the past.

The court's approach in Solesky was not an entirely new one, but rather, it was a variation of the first approach. It still required proof on the part of the plaintiff; however it recognized the possibility of meeting the burden based on a different type of proof. Thus, conceptually, Solesky was neither a big departure from the applicable law at the time nor an adoption of the alternative, and more prevalent, view in other jurisdictions.

The court in Solesky attempted to modify the common law in order to adapt to the available evidence of a social issue without destroying the common law's doctrinal basis. In contrast, the House and the Senate's reaction to Solesky was a refusal to consider an alternative and an attempt to force a choice between the two first approaches. When that failed, they agreed to compromise on what appears to be an entirely different approach. Unfortunately, it is not.

For cases against dog owners, the key provision of the new statute is the recognition that an injury caused by a dog creates a

85 See Maryland Legislature Mutes Landmark Ruling, Tracey v. Solesky, During 2014 Legislative Session, DogsBite Blog (June 2, 2014), http://blog.dogsbite.org/2014/06/ maryland-legislature-mutes-landmark-ruling-tracey-v-solesky.html. 
rebuttable presumption that the dog's owner knew or should have known that the dog had vicious or dangerous propensities. ${ }^{86}$ The reference to the element of knowledge, of course, suggests that the statute is based upon the traditional Restatement approach. The statute exempts the plaintiff from having to prove the knowledge at first, but since the presumption is rebuttable, once rebutted, plaintiffs will find themselves in exactly the same position they would have been in before Solesky was decided. Therefore, whether the change benefits the victims will depend on how easy it will be to rebut the presumption. This explains why this very question was a point of contention that delayed the approval of the statute to begin with.

With no guidance on how the presumption can be rebutted other than the fact that the question will always be an issue for the jury, the parties are essentially on notice that they should always prepare to litigate the case to the end. For plaintiffs, this means that they need to be ready to present evidence to support the element of knowledge. This is because they will never know whether the jury will find the defendant's arguments sufficient to defeat the presumption before going to trial, or whether the judge might issue a judgment notwithstanding the verdict after the trial. In other words, when preparing their case, plaintiffs will see no effect whatsoever from the presumption that supposedly relieves them from the duty to prove the defendant's, and may, in fact, face higher costs in preparing for litigation.

For defendants, on the other hand, the statute eliminates the possibility of winning on summary judgment by asking the court to conclude that the evidence shows as a matter of law that the presumption has been rebutted. This means that, unless the defendants can support a motion to dismiss based on different issues, they will always have to face trial, which will definitely increase their litigation costs.

Perhaps the effect of the new statute will be to encourage the parties to settle given the increased costs and the uncertainties of a possible trial. This is always a good thing, but no different than in any other torts case. In the end, the statute seems like a convoluted way to end in the same place the law was back in March of 2012.

In cases against landlords, the effect of the statute is the same but more straightforward. As the statute itself states, "in an action against a person other than the owner of a dog ... the common law

86 Md. Code Ann., Cts. \& Jud. Proc. § 3-1901 (West 2014). 
of liability . . that existed on April 1, 2012 . . is retained . . ."87

Having traveled back in time, the question for the jurisdiction remains the same: which approach would advance the best public policy? The answer is that the majority of the state senators had it right in 2012. There is a reason the majority of jurisdictions have decided to adopt a strict liability approach to the issues raised by injuries caused by dogs. It is the better approach and, if for some reason that seems unacceptable, it is Solesky that provides a good compromise.

Proponents of the common law traditional approach argue it is unfair to impose liability on pet owners who were not negligent and who had no notice that their pets had a propensity to cause injury. Yet, most jurisdictions have taken the position that it is not unfair because pet owners must understand that any pet has the potential to cause injury to others and, therefore, pet ownership carries with it the possible costs of being responsible for those injuries. ${ }^{88}$

As is typical in tort law, the issue comes down to a cost benefit analysis. The costs attached to possible liability are less than the benefits gained by imposing strict liability. ${ }^{89}$ The principle of strict liability is based on the fact that certain activities or circumstances create high levels of risk of injury. ${ }^{90}$ As a society, we accept those risks because the activities also offer certain benefits. In order to get the benefits, we are willing to take the risks; but, we have also decided to ensure that those who create the risk understand their responsibility for possible injuries because they are in a better

87 Md. Code ANN., CTS. \& Jud. Proc. § 3-1901(b) (West 2014).

88 See File v. Duewer, 869 N.E.2d 432 (Ill. App. 2007) (noting that the Animal Control Act imposes strict liability because it is intended to protect those who may not have any way of knowing or avoiding the risk the animal poses to them); Beggs v. Griffith, 913 N.E.2d 1230 (2009) (explaining that, because liability is mandated under the Animal Control Act for injuries caused by animals, the existence of the law serves as an incentive to keep one's animals from harming another); Garcia v. Nelson, 759 N.E.2d 601 (2001) (discussing how the purpose of the Animal Control Act is to protect public by encouraging tight control of animals).

89 This view is reflected in comments $\mathrm{d}$ and e to section 509 of the Restatement (Second), which support the view that there is no social value in keeping animals that are vicious or have other dangerous propensities that are in excess of those necessary for their utility and are abnormal to their class. RESTATEMENT (SECOND) OF TORTS $§ 509$ cmts. d, e (1965).

90 See DobBs, supra note 24, at 942 (explaining that strict liability cases have in common the fact that the defendant creates or introduces a dangerous condition not commonly accepted in society). See also Indiana Harbor v. American Cyanamid, 916 F.2d 1174, 1177 ( $7^{\text {th }}$ Cir. 1990) ("IT]he greater the risk . . . the stronger . . . the case for strict liability."). 
position to manage the costs of the possible injuries. ${ }^{91}$ This is the basic principle behind the notion of strict liability for inherently or abnormally dangerous activities and for liability for injuries caused by animals. ${ }^{92}$ Thus, dog owners need to be on notice that all dogs create certain risks and must be ready for the consequences of possible liability because of those risks. Likewise, landlords must also be on notice that leasing properties to tenants with dogs carries with it the risk of possible liability. Owners and landlords can manage those risks by obtaining insurance and taking other necessary precautions to prevent possible injuries. ${ }^{93}$ Given the risks involved, the additional costs related to insurance are just part of the costs of dog ownership and of leasing properties to dog owners. Though it has been argued that it is difficult to obtain insurance, the Department of Legislative Services of the Maryland General Assembly has concluded that insurance costs are not higher in states that have adopted a strict liability approach. ${ }^{94}$ The Department has also concluded that only three of the top ten insurers who provide homeowners insurance in Maryland have exclusions or limits on coverage for injuries caused by specific dog breeds. ${ }^{95}$ In addition, the fact that the need to obtain insurance and prepare for possible eventualities may raise costs for owners and landlords does not mean it is unfair. All it means is that it is better to place the possible responsibility for injuries on those who are in the best position to manage the costs of those possible injuries.

91 See DoBBs, supra note 24, at 950 (explaining that the idea behind strict liability is not necessarily to deter certain activities altogether, but to make them "pay their way" by charging them with liability for harms).

92 See DobBs, supra note 24, at 942 (explaining that strict liability cases have in common the fact that the defendant creates or introduces a dangerous condition not commonly accepted in society). See also Indiana Harbor v. American Cyanamid, 916 F.2d 1174, 1177 ( $7^{\text {th }}$ Cir. 1990) (" $[\mathrm{T}]$ he greater the risk . . . the stronger . . . the case for strict liability.").

93 Md. Gen. Assemb. Dep't of Legis. Servs., Fiscal and Policy Note, H.B. 732014 Sess., at 5 (2014), available at http://mgaleg.maryland.gov/2014RS/fnotes/bil_0003/ hb0073.pdf; Md. Gen. Assemb. DeP'T Of Legis. Servs., Fiscal and Policy Note, S.B. 247, 2014 Sess., at 5 (2014), available at http://mgaleg.maryland.gov/2014RS/fnotes/ bil_0007/sb0247.pdf.

94 Md. gen. Assemb. Dep't of Legis. Servs., Dog Bites in Other States: Data InSURANCE COVERAGE, AND LIABILITY, 2013 Sess., at 23 (2014). See also supra note 53.

95 See supra note 53 


\section{CONCLUSION}

Because it attempted to modify the common law, and because it used a breed-specific approach, Tracey $v$. Solesky has been criticized and eventually abrogated. Yet, upon closer examination, it should be clear that the decision of the court was not an example of "panic policymaking," to borrow the ABA's description of breed-specific regulation. It was neither a big departure from the applicable law at the time nor an adoption of the alternative, and more prevalent, view in other jurisdictions. If there was any "panic policymaking," it was the scramble by the legislature to find a way to revert back to the common law predating the case. A more careful consideration of the options available for balancing the interests involved should have resulted in either adopting the prevalent view in the majority of jurisdictions or in an understanding of how Solesky actually advanced a better public policy than the common law it modified.

Instead, as a result of the recently adopted statute enacted to abrogate the result in Solesky, the law as it stands is a collage of different approaches to deal with the same problem. There is a standard that applies to owners of dogs that cause injuries while at large and a different standard that applies to other dog owners and to landlords; but, the latter is applied differently depending on whether the defendant is an owner or a landlord. If nothing else, it would be easier to simply adopt a better standard for all cases involving injuries caused by dogs.

Additionally, although the effect of the newly adopted statute may make it slightly easier for plaintiffs to support a claim in the initial stages or to settle it, it is more favorable to dog owners and landlords. The statute does very little to balance the interests involved. If anything, the statute essentially returns the law to what it was under the traditional approach, while maybe encouraging the parties in a lawsuit to settle before taking their chances with a jury. This is not entirely a bad thing; however, since the vast majority of lawsuits settle anyway, it does not sound like a major change or an advantage to the victims.

Rather than creating different standards and reverting to the old common law, the legislature should have adopted a non-breedspecific strict liability standard, just like the one adopted by the majority of American jurisdictions. It is unfortunate that it took two years to enact a new "compromise statute" that is really no compromise at all, but instead, paves the way back to the past. 